\title{
Elaboration and validation of a diagrammatic scale to assess downy mildew severity in grapevine
}

\author{
Elaboração e validação de uma escala diagramática para quantificação da severidade do míldio da \\ videira
}

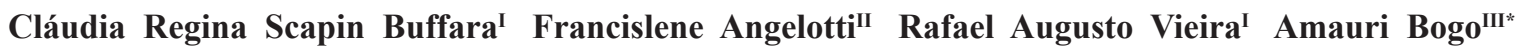 \\ Dauri José Tessmann' Betina Perreira de Bem ${ }^{\text {III }}$
}

\begin{abstract}
The downy mildew, caused by Plasmopora viticola, is one of the most important grapevine (Vitis vinifera) diseases in Southern Brazil, causing defoliation and economic losses. The evaluation of disease severity is an important decision for adoption of strategies and tactics for disease control. Therefore, the objective of this work was to elaborate and to validate a diagrammatic scale to assess downy mildew severity in grapevine, respecting the limitations of visual acuity. The diagrammatic scale with seven levels of disease severity of 1, 3, 6, 12, 25, 50 and $75 \%$ was developed in two versions of black-and-white and color scale. The scales were tested and validated by eight raters with and without previous experience with grapevine downy mildew. The raters estimated the severity of 30 grapevine leaves with different downy mildew severity, with and without the use of the scales. Minimum, intermediate and maximum severity levels were collected according to Weber-Fechner's stimulus-response law. The accuracy and precision were analyzed by linear regression between the actual and the estimated severity. Actual severity was assessed with ASSESS ${ }^{\circledast}$ Program. The scales provided good levels of accuracy (means of 88\%) and excellent levels of precision (means of 95\%). The raters showed great precision and accuracy when used the diagrammatic scale. The color scale provided more precise and accurate estimates than the black-and-white scale. The scale proposed in this work presented appropriate applicability for downy mildew evaluation in grapevine.
\end{abstract}

Key words: disease assessment, pathometry, Plamospara viticola, Vitis vinifera.

\section{RESUMO}

O míldio da videira causado pelo fungo Plasmopora viticola é uma das doenças mais importantes da videira (Vitis vinifera) no sul do Brasil, causando desfolha e perdas econômicas.
A avaliação da severidade de doenças é uma decisão importante na adoção de estratégias e táticas de controle. Assim, o objetivo deste trabalho foi elaborar e validar uma escala diagramática para a avaliação da severidade do míldio da videira, respeitando as limitações da acuidade visual. A escala diagramática com sete níveis de severidade: 1, 3, 6, 12, 25, 50 e 75\%, foi desenvolvida em duas versões preto-e-branco e em cores. As escalas foram avaliadas e validadas por oito avaliadores com e sem experiência prévia com o míldio da videira. Os avaliadores estimaram a severidade em 30 folhas de videira com diferentes níveis de severidade da doença, com e sem experiência no uso da escala diagramática. Severidades mínimas, médias e máximas foram obtidas pela Lei do estímulo visual de Weber-Fechner. A acurácia e a precisão foram analisadas por meio de regressão linear, confrontando os valores de severidade reais com os estimados. A severidade real foi estimada pelo programa ASSESS ${ }^{\circledR}$. As escalas proporcionaram bons níveis de acurácia (média 88\%) e excelentes níveis de precisão (média de 95\%). Os avaliadores apresentaram grande precisão e acurácia com o uso da escala diagramática. A escala colorida proporcionou estimativa melhor de precisão $e$ acurácia do que a escala preto-e-branco. A escala diagramática proposta apresenta apropriada aplicabilidade para a avaliação do míldio da videira.

Palavras-chave: Avaliação de doenças, patometria, Plamospara viticola, Vitis vinifera.

\section{INTRODUCTION}

The annual Brazilian grapevine (Vitis sp.) production is over 1.5 million tons, half sold as table grapes and the other half as grapes for processing. Considering the latter segment, wine is an important product due to the added value it transfers to wineries

'Departamento de Agronomia, Universidade Estadual de Maringá (UEM), Maringá, PR, Brasil.

IE Empresa Brasileira de Pesquisa Agropecuária, Embrapa Semiárido, Petrolina, PE, Brasil.

IIIPrograma de Pós-graduação em Produção Vegetal, Universidade do Estado de Santa Catarina (UDESC), Av. Luis de Camões 2090,

88520-000, Lages, SC, Brasil. E-mail: amauribogo@udesc.br.*Autor para correspondência. 
and grape growers (MIELE et al., 2010). Southern region of Brazil responds for nearly $75 \%$ of the national grapevine production. The expansion of the area used for grapevine production in this region, in addition to conduction systems and pruning methods, contribute to rise the intensity of several diseases, amongst them downy mildew, caused by Plasmopora vitícola (Berl. \& De Toni). Downy mildew is one of the most important grapevine diseases in Southern Brazil, where can causes up to $70 \%$ reduction in fruit production (GARRIDO \& ANGELOTTI, 2011).

The fungus causes direct yield damages by rotting inflorescences, berries, clusters and shoots. Indirectly, can result premature vineyards defoliation due to foliar infections. Although all green parts of the grapevine are susceptible, the first symptoms of downy mildew are usually seen on the leaves as soon as five to seven days after infection. Foliar symptoms appear as yellow circular spots with an oily appearance (oilspots). Young oilspots on young leaves are surrounded by brownish-yellow halo. As lesions expand, the affected areas turn brown, necrotic or mottled. Under favorable weather conditions, a delicate, dense, and white to grayish cottony growth mycelia cover most of the leaf surface. In late summer and early fall, the diseased leaves take on a tapestrylike appearance when the growth of the pathogen is restricted by the veinlets, causing premature fall and underdeveloped fruits (FICKE et al., 2002). Pathogen infection causes destruction of inflorescences during flowering. Bunches, berries and rachis also are covered with white downy growth, progressing to brown, making the bunches dried and consequent total loss of production (NAVES et al., 2005).

For any program of integrated disease management to succeed, it is crucial to assess disease intensity with accuracy and precision. Accuracy refers to how faithful an estimate is from the actual amount of the evaluated disease, while precision corresponds to the confidence and/or repeatability associated to such estimate (GODOY, 2006; ANGELOTTI et al., 2008; MICHEREFF et al, 2009). However, the precise quantification of infected area is a difficult task. However, among the proposed strategies for disease severity assessment, diagrammatic scales are valuable tools for plant disease epidemiology and control. These scales can be used to standardize the severity estimation and reduce the subjective of disease severity visual estimates. The diagrammatic scales is expected to be easy and quick for a wide range of conditions with reproducible, accurate, and precise results (MALAGI et al., 2011; SACHS et al., 2011; SANTOS et al., 2011; YADAV et al.,
2012). Accuracy refers to how faithful an estimate is from the actual amount of the evaluated disease, while precision corresponds to the confidence and/or repeatability associated to such estimate (NUTTER JR. \& SCHULTZ, 1995, ANGELOTTI et al., 2008; MICHEREFF et al., 2009). Downy mildew is a leaf spot and its intensity is expressed by assessing severity (percent or proportion of affected leaf area). Most of the times, disease severity is assessed visually and it is prone to large subjectivity, which can give rise to significant errors in accuracy and precision (NUTTER JR. et al., 2006; ANGELOTTI et al., 2008; MICHEREFF et al., 2009). Therefore, this work aimed to develop and validate a diagrammatic scale for assessing grapevine downy mildew severity.

\section{MATERIAL AND METHODS}

Development of diagrammatic scale. To develop the diagrammatic scale, 30 grapevine leaves of 'Italia' cultivar ranging from minimum to maximum levels of downy mildew severity were collected from a commercial vineyard located at Lages/SC municipality. Leaves with mixed symptoms with others grape diseases were not included in the analysis. The leaves were photographed with a digital camera at approximately $15 \mathrm{~cm}$ high and the images were used for assessing the percentage of leaf area affected by the disease with the software ASSESS ${ }^{\circledR}$ (LAMARI, 2002). The images in two versions of black-and-white and color were used to determine the minimum, maximum and intermediate levels of disease severity occurring in field. The determination of severity levels of the scale was according to Weber-Fechner's stimulus-response law (HORSFALL \& COWLING, 1978; CAMPBELL \& MADDEN, 1990).

Validation of diagrammatic scale. The proposed scale was validated based on analysis of precision, accuracy and reproducibility of assessments. The validation was performed based on images of 30 grapevine leaves showing downy mildew symptoms at different severity levels, assessed by eight persons, divided into two groups: inexperienced (four persons without experience in the quantification of the disease and without previous contact with the scale) and experienced (four persons that had worked with downy mildew quantification before, using the proposed scale). The accuracy and precision of the assessments of each rater were determined by linear regression, where actual severity was the independent variable and estimated severity the dependent variable. The accuracy of the estimates of each rater was determined by t-test 
applied to the slope coefficient (b), to verify whether they were significantly different from 1.0, and to the intercept (a) to verify whether they were significantly different from zero. The precision of assessments was estimated by the coefficient of determination $\left(R^{2}\right)$ of the regression line and by the variance of the absolute errors (estimated severity minus actual severity) for each assessment (KRANZ, 1988; CAMPBELL \& MADDEN, 1990; NUTTER JR. \& SCHULTZ, 1995; ANGELOTTI et al., 2008. Intercept values minor than 0 indicated overestimates and major than 0 indicate underestimates. Angular coefficient values major than 1indicated overestimates and minor than 1 indicated underestimates.

\section{RESULTS AND DISCUSSION}

A diagrammatic scale having severity levels of 1, 3, 6, 12, 25, 50 and 75\% in black-and-white and in color version were proposed in this work (Figure 1). The scales represents yellow circular spots with an oily appearance (oilspots) surrounded by brownishyellow halo on the upper surface and brown, necrotic or mottled area with grayish-white sporulation of $\boldsymbol{P}$. viticola on the lower surface of the grapevine leaves. Even though the minimum level of grapevine downy mildew severity in the scale was $1.0 \%$, this level may actually be lower in field. However, severity levels below $1 \%$ are not practical, since the early symptoms are few oilspots which are difficult to visualize. The scale levels can be subdivided into smaller intervals (NASCIMENTO et al., 2005; KOWATA et al., 2008; LENZ, et al., 2010). However, it must be prepared based on the law of Weber-Fechner visual acuity and presenting logarithmic increments between severity levels (NUTTER JR. \& SCHULTZ, 1995; ANGELOTTI et al., 2008). The maximum severity on leaves was around $75 \%$ and severity over it induced defoliation with most of the leaves covered by the fungus reproductive structures of sporangiospores.

The analysis of accuracy was applied to verify how close the estimate severity levels were to actual severity (NUTTER JR. \& SCHULTZ, 1995; ANGELOTTI et al., 2008) and the estimated severity values were close to the actual severity values for most of the raters (Figure 2). Figure 2 show the linear

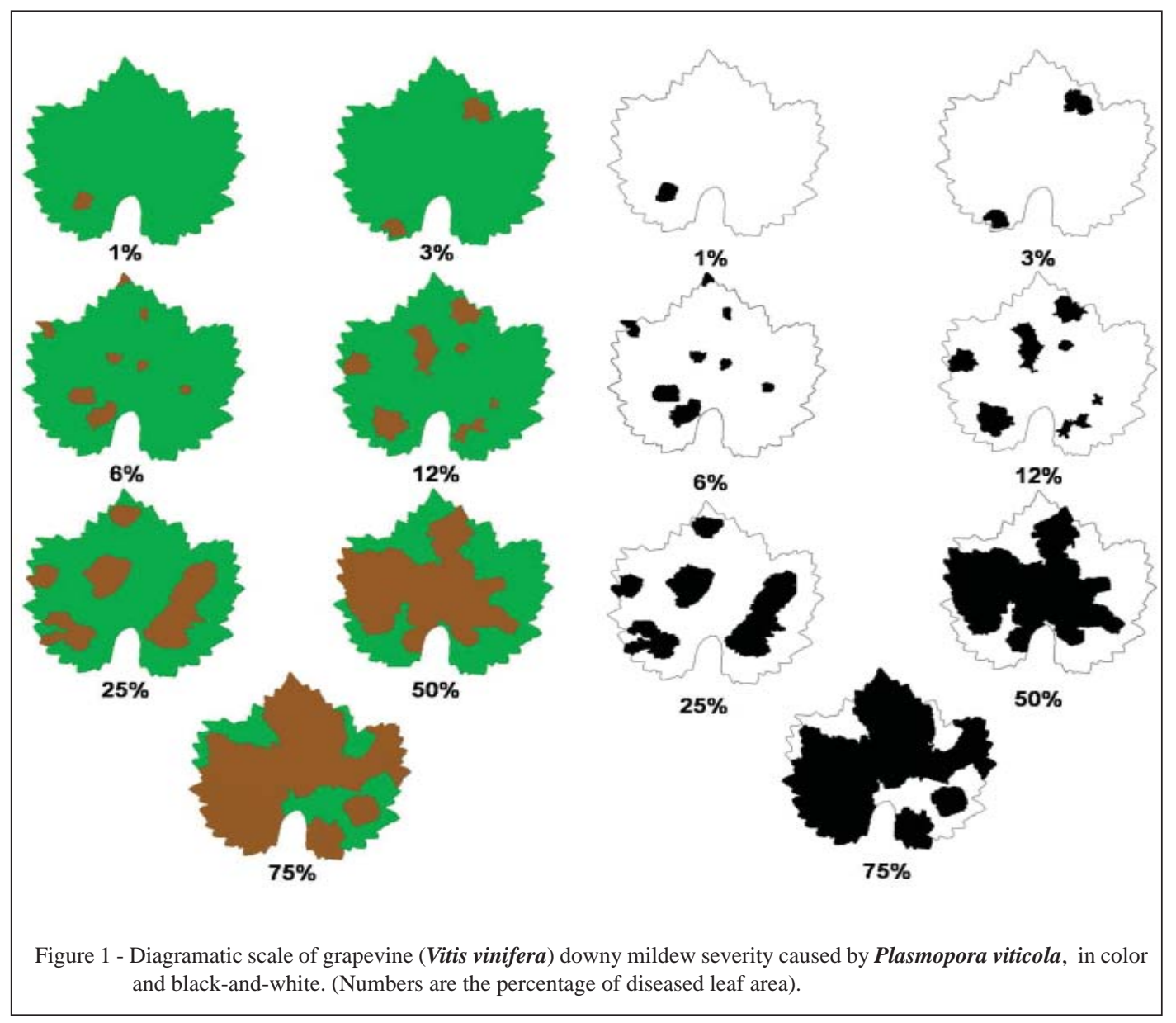

Ciência Rural, v.44, n.8, ago, 2014. 


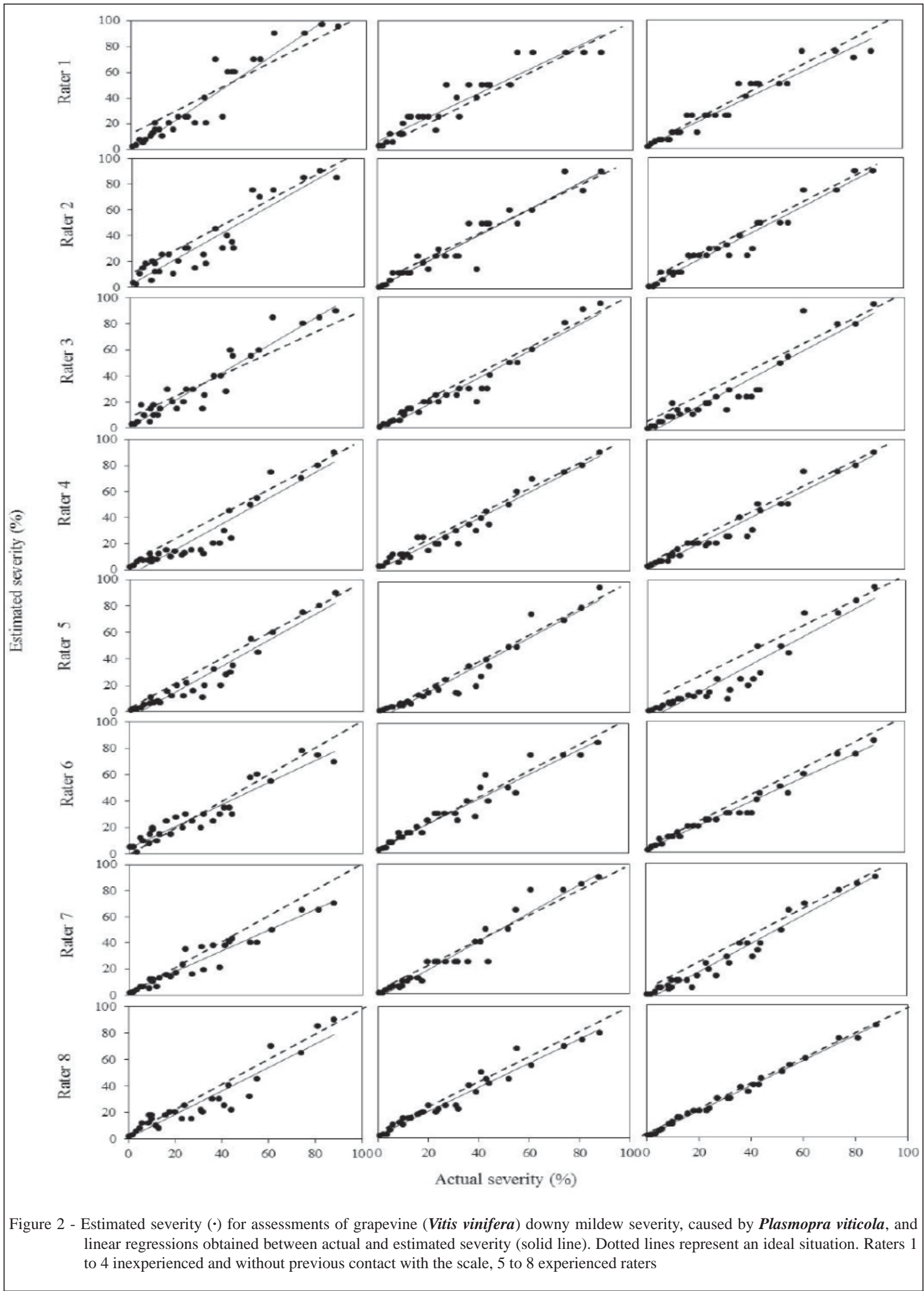

Ciência Rural, v.44, n.8, ago, 2014. 
regressions obtained between actual and estimated severity for all raters, without and with the scales. Without use of the diagrammatic scale, the values of the intercept parameter (a) were significantly different from 1.0 for raters 5 and 6 , meaning that the assessments done by these raters were not accurate (Table 1). With the black-and-white scale raters 5, 7 and 8 were not accurate, and with the color scale raters 1 and 5 were not accurate. However, when the slope coefficients (b) were taken on consideration, without use of the diagrammatic scale, the raters 6 and 7 were not accurate. With the black-and-white scale the only rater 8 was not accurate, and with the color scale non raters were not accurate (Table 1 ). Thus, this parameter (b) indicated that the diagrammatic scale improved accuracy of assessments for most of raters and the color scale improved accuracy in relation to the black-and-white scale.

The analysis of precision was applied to verify the repeatability or variation associated with an estimate, regardless of the mean value. Precision is estimated by the coefficient of determination $\left(\mathrm{R}^{2}\right)$ and by the variance of the absolute errors (estimated severity minus actual severity) (NUTTER \& SCHULTZ, 1995; ANGELOTTI et al., 2008). The $\mathrm{R}^{2}$ for assessments without aid of the scale, with color scale, and with black-and-white scale ranged from 0.75 to 0.93 (average 0.8877 ), 0.89 to 0.95 (average 0.9369 ), and 0.88 to 0.99 (average 0.9341 ), respectively. The precision was lower of 0.75 when the raters did not use the scale. However, the precision was slightly improved with aid of color scale than in black-and-white scale when the $\mathrm{R}^{2}$ average was taken into consideration (Table 1). The variance of absolute errors among raters, with and without aid of the scales, is shown in figure 3. The precision was confirmed by the variation of the absolute errors.

The precision of assessments can also be evaluated by analyzing the reproducibility of measurements among raters when assessing the same sample (NUTTER JR. et al., 2006; ANGELOTTI et al., 2008). The figure 3 showed the most of the assessment errors occurred in the range of 20 to $45 \%$ of severity. These results corroborated with BELASQUI JR. et al (2005), ANGELOTTI et al. (2008) and CAPUCHO et al. (2012) were the assessment error of citrus canker, grapevine rust and coffee leaf rust were in the range from 20 to $50 \%$ for inexperienced raters, and from 10 to $25 \%$ for experienced raters.

The use of a standard system for disease evaluation is the most effective way to allow the confrontation of results from different groups, institutions, and places (BERGAMIN FILHO \& AMORIM, 1996; MICHEREFF et al., 2009). Therefore, this diagrammatic scale to assess downy mildew severity in grapevine is considerated to be a valuable tool for field surveys, epidemiological studies, and comparison among disease control methods.

\section{CONCLUSION}

The color diagrammatic scale provided better accuracy and precision than the black and-

Table 1 - Intercepts (a), slope coefficients (b) and coefficients of determination $\left(\mathrm{R}^{2}\right)$ of the regression linear for actual (independent variable) versus estimated severity (dependent variable) of severity of grapevine downy mildew (Plasmopara viticola), for eight raters (1 to 4 inexperienced and without previous contact with the scale, 5 to 8 experienced raters) without the diagrammatic scale and with color and black-and-white diagrammatic scale.

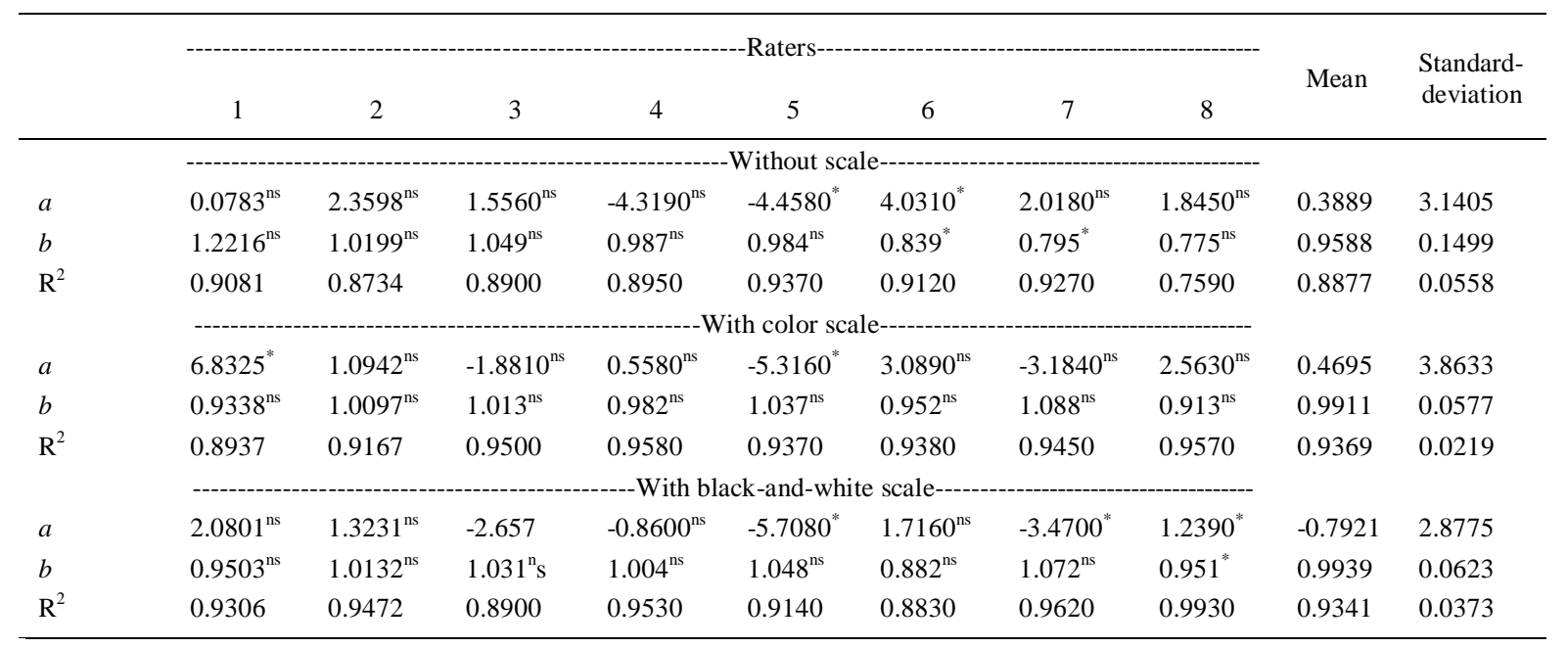




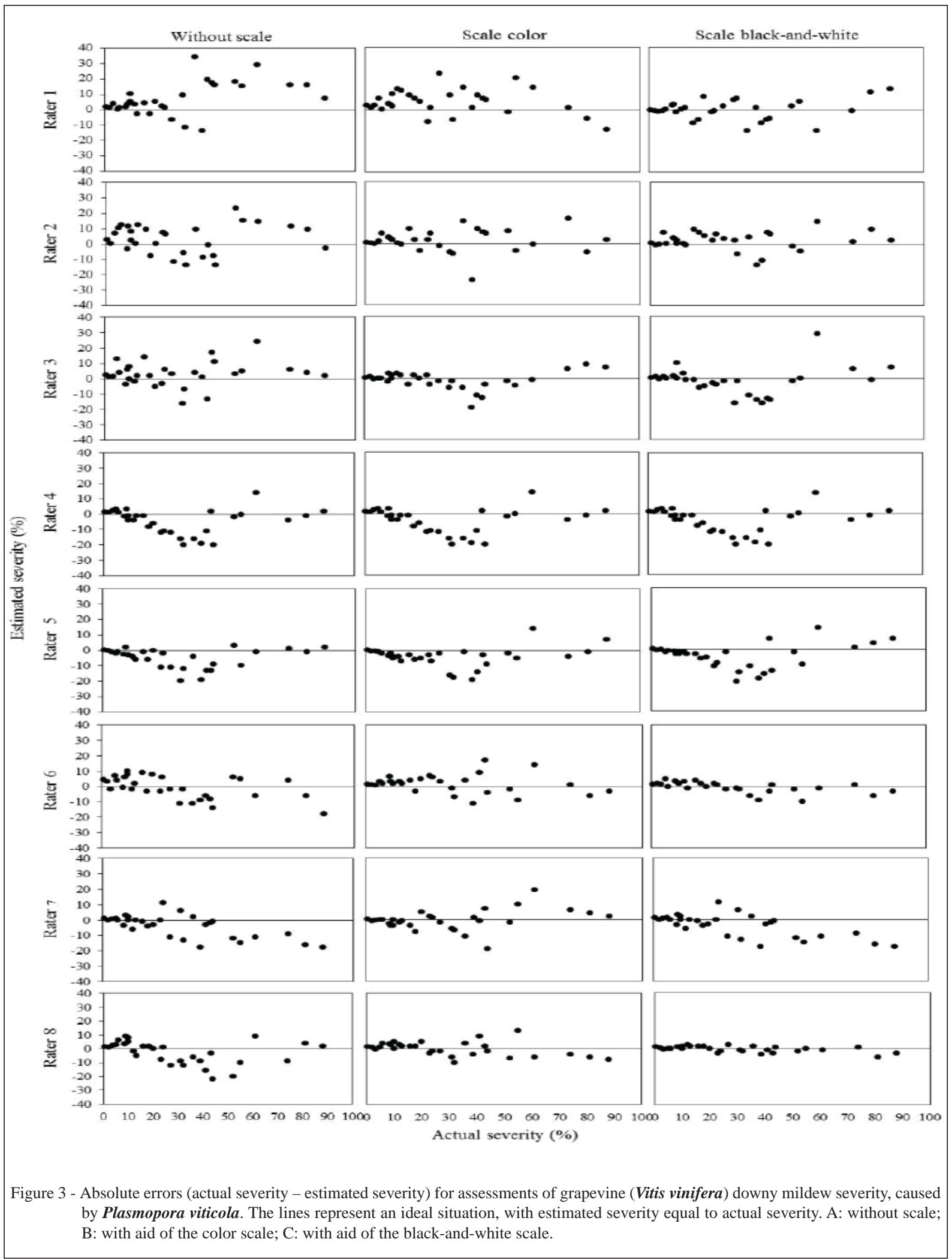

Ciência Rural, v.44, n.8, ago, 2014. 
white scale when the $\mathrm{R}^{2}$ average was taken into consideration.

The utilization of a diagrammatic scale for quantification of grapevine downy mildew severity was very useful, easy to managing and effective in providing a quick disease estimate, with good accuracy, precision and reproducibility.

\section{ACKNOWLEDGEMENTS}

Authors thank the raters who took part in the scale validation. The CNPq (The National Council for Scientific and Technological Development), CAPES (Coordination for the Improvement of Higher Level -or Education- Personnel), FAPESC (Santa Catarina State Foundation for Research Support) for Research Grant and financial support.

\section{REFERENCES}

ANGELOTTI, F. et al. Diagrammatic scale for assessment of grapevine rust. Tropical Plant Pathology, v.33 n.6, p.439-443, 2008. Available from: <http://www.scielo.br/-pdf/tpp/v33n6/ v33n6a06.pdf.> Accessed: Jan. 15, 2013. doi: 10.1590/S198256762008000600006 .

BERGAMIN FILHO, A.; AMORIM, L. Doenças de plantas tropicais: epidemiologia e controle econômico. São Paulo: Ceres, 1996. 299p.

CAMPBELL, C.L.; MADDEN, L.V. Introduction to plant disease epidemiology. New York: John Wiley \& Sons. 1990. 532p.

CAPUCHO, A.S. et al. Development and validation of a standard area diagram set to estimate severity of leaf rust in Coffea arabica and C. canephora. Plant Pathology, v.60, n.6, p.1144-1150, 2012. Available from: <http://onlinelibrary.wiley.com/doi/10.1111/ j.13653059.2011.-02472.x/pdf>. Accessed: Fev. 10, 2013. doi: 10.1111/j.1365-3059.2011.02472.x

FICKE,A.etal. Ontogenic Resistance andPlantDisease Management: A Case Study of Grape Powdery Mildew. Phytopathology, v. 92, n. 6, p. 671-675, 2002. Available from: <http://apsjournals.apsnet.org/ doi/abs/10.1094/PHYTO.2002.92.6.671.> Accessed: Apr. 01, 2014. doi: 10.1094/PHYTO.2002.92.6.671

GARRIDO, L.R.; ANGELOTTI, F. Impacto potencial das mudanças climáticas sobre as doenças da videira no Brasil. In: GHINI, R. et al. (Ed.). Impactos das mudanças climáticas sobre doenças de importantes culturas no Brasil. Jaguariúna: Embrapa Meio Ambiente, 2011. p.331-356.

GODOY, C.V. et al. Diagrammatic scale for assessment of soybean rust severity. Fitopatologia Brasileira, v.31, p.63-68, 2006. Available from: <http://www.scielo.br/scielo.php?pid=S0100-41582006000100011\&script=sci_arttext. $>$ Accessed: Jan. 05, 2013. doi: 10.1590/S0100-41582006000100011.

HORSFALL, J.G.; COWLING, E.B. Pathometry: the meaurement of plant disease. In: (Ed.). Plant disease an advance treatise. How disease develops in populations. New York: Academic, 1978. V.2, p.122-157.
KRANZ, J. Measuring plant disease. In: KRANZ, J.; ROTEM, J. (Ed.). Experimental techniques in plant disease epidemiology. Berlin: Springer, 1988. p. 47-62.

KOWATA, L.S. et al. Escala diagramática para avaliar severidade de míldio da soja. Scientia Agrária, v.9, p.105-110, 2008. Available from: <http://www.redalyc.org/pdf/-995/99516828017. pdf $>$. Accessed: Jan. 25, 2013.

LAMARI, L. Image analysis software for plant disease quantification. St. Paul, Minnesota: APS-Press, 2002. 299p.

LENZ, G. et al. Escala diagramática para avaliação de severidade de mancha-parda em arroz. Ciência Rural, v.40, n.4, p.752-758, 2010. Available from: <http://www.scielo.br/-scielo.php?pid=S010384782010000400002\&script=sci_arttext. $>$ Accessed: Jan. 22, 2013. doi: 10.1590/S0103-84782010005000061.

MALAGI, G. et al. Elaboração e validação da escala diagramática para avaliação da mancha branca do milho. Revista Ciência Agronômica, v.42, n.3, p.797-804, 2011. Available from: <http://www.ccarevista.ufc.br/seer/index.php/ccarevista/article/ view/1269/606.> Accessed: Fev. 03, 2013. doi: 10.1590/S180666902011000300028.

MIELE, A. et al. Discrimination of Brazilian red wines according to the viticultural region, varietal, and winery origin. Ciência Tecnologia Alimentar, v.30, n.1, p.268-275, 2010. Available from: <http://dx.doi.org/10.1590/S0101-20612010000100039>. Accessed: Nov. 18, 2013. doi: 10.1590/S0101-20612010000100039.

MICHEREFF, S.J et al. Diagrammatic scale to assess downy mildew severity in melon. Horticultura Brasileira, v.27, n. 1, p.76-79, 2009. Available from: <http://www.scielo.br/scielo.php?pid=S010205362009000100015\&script=sci_arttext.> Accessed: Nov. 15, 2013. doi: 10.1590/S0102-05362009000100015.

NASCIMENTO, A.R.P. et al. Elaboração e validação de escala diagramática para cancro bacteriano da videira. Summa Phytopathologica, v.31, p.59-64, 2005. Available from: <http:// www.pgfitopat.ufrpe.br/publicacoes/samiescvid.pdf.> Accessed: Fev. 15, 2013

NAVES, R.L. et al. Doenças fúngicas e bacterianas em uva. Sistema de produção 8. Bento Gonçalves/RS: Embrapa Uva e Vinho, 2005.

NUTTER, J.R. et al. Disease assessment concepts and the advancements made in improving the accuracy and precision of plant disease data. European Journal of Plant Pathology, v.115, p.95-103, 2006. Available from: <http://link.springer.com/chapter /10.1007\%2F1-4020-5020-8_7.> Accessed: Nov. 03, 2013. doi: 10.1007/S10658-005-1230-z.

NUTTER JR.; F.W.; SCHULTZ, P.M. Improving the accuracy and precision of disease assessments: selection of methods and use of computer-aided training programs. Canadian Journal of Plant Pathology, v.17, p.174-184, 1995. Available from: <http:// www.tandfonline.com/doi/pdf/-10.1080/07060669509500709\#. Uop6ZsSkpi.> Accessed: Nov. 15, 2013.

SACHS, P.J.D. et al. Escala diagramática para avaliação da severidade da manchabranca em milho. Summa Phytopathologica, 
v.37, n.4, p.202-204, 2011. Available from: <http://www.scielo. br/scielo.php?pid=S0100-54052011000400007\&script $=$ sci arttext.> Accessed: Nov. 15, 2013. doi: 10.1590/S010054052011000400007.

SANTOS, P.H.D. et al. Elaboração e validação de escala diagramática para avaliação da severidade de oídio em folhas de mamoeiro. Summa Phytopathologica, v.37, n.4, p.215-217, 2011.
Available from: <http://www.scielo.br/scielo.php?pid=S010054052011000400011\&script=sci_arttext.> Accessed: Nov. 15, 2013. doi: 10.1590/S0100-54052011000400011.

YADAV, N.V.S. et al. Development and validation of standard area diagrams to aid assessment of pecan scab symptoms on fruit. Plant Pathology, v.62, n. 2, p.1-11, 2012. 